\title{
HPV-16 E6 Peptides Vaccine/Candida albicans Extract
}

National Cancer Institute

\section{Source}

National Cancer Institute. HPV-16 E6 Peptides Vaccine/Candida albicans Extract. NCI

Thesaurus. Code C102874.

A human papillomavirus (HPV) type 16 vaccine containing four E6 peptides in combination with an extract of Candida albicans, with potential immunomodulating activity. Upon administration of HPV-16 E6 peptides vaccine/Candida albicans extract, the four HPV-16 E6 peptides and the Candida albicans may activate the immune system to mount a cytotoxic T-lymphocyte $(\mathrm{CTL}$ ) response against cells expressing the E6 oncoprotein, resulting in tumor cell lysis. The HPV 16 transforming protein E6 is expressed in precancerous and malignant cervical lesions. Candida albicans allergenic extract may be used as a recall antigen to stimulate the immune system against HPV. 